\title{
Biodiversity Disruption
}

\author{
Ali Farag Alznad \\ Phd ,Candidate \\ DOI: 10.29322/IJSRP.10.07.2020.p10369 \\ http://dx.doi.org/10.29322/IJSRP.10.07.2020.p10369
}

\begin{abstract}
Human impact on the environment has multiple effects most of them are unpredictable. All problems of the disturbed environment are by their nature predominantly ecological and, in essence, they represent a violation of the ecological paradigm of the functioning of life on Earth. Man on Earth today can cause a biological catastrophe at any moment, it can lead to the extinction of organic species. The demographic explosion of populations from the end of the 20th century, accompanied by an enormous increase in resource consumption, gave human destructiveness a completely new dimension.
\end{abstract}

Index Terms- Human,Environment,Biological,Ecological.

\section{INTRODUCTION}

$\mathrm{S}^{\mathrm{p}}$ pecies extinction is, from an evolutionary and biological point of view, a normal process. However, what we will face in the coming years are not such natural evolutionary changes in the composition of the living world, but the mass and irreversible destruction of the living world by man. This alarming rate of extinction of organic species becoming the main global or biological problem. The destruction of an increasing number of organic species is directly related to the destruction of their habitats.

Organic species are carriers of a specific combination of genes (each species is an original and unique form of life) and specific functions in certain ecosystems, and their anthropogenically conditioned extinction or endangerment actually represents the most direct reduction of the total biodiversity of the Earth.

\section{IMPORTANCE OF BIODIVERSITY}

We discover the importance of biodiversity in the fact that the totality of all life forms on Earth is a much more complex phenomenon than the total sum of individual organic species. Biodiversity as a phenomenon includes the diversity of ecological interactions. The diversity of ecological relationships have been established between different species over many years and form the basis of existence, complexity, stability, and functioning of each individual ecosystem, biome or biosphere as a whole, as well

\footnotetext{
${ }^{1}$ Mani, M., Markandya, A. and Ipe, V. 2008. Policy and Institutional Reforms to Support Climate Change Adaptation and Mitigation in Development Programs, pp 78. Washington: The International Bank for Reconstruction and Development; The World Bank.
}

as the survival, future and evolution of every organic species, including the species Homo sapiens. Without biodiversity there are no biogeochemical cycles and oxygen production, no ecosystem functioning, no photosynthesis or decomposition of organic matter.

Preserved biodiversity contributes to climate regulation, reduces the effect of greenhouse gases, maintains air and water quality, acts as a drought and flood controller ... Biodiversity provides us with life support systems, and the entire evolution of Homo sapiens species, and thus human civilization in general, is related to the use of a wide range of biological resources.

Biodiversity increases the resistance of physical and biological systems to changing conditions environment and climate change, because genetically rich populations and ecosystems are rich species have a greater potential for adaptation. ${ }^{1}$ Ecosystem builds resilience on bases of following characteristics: the ability to resist change (ecosystem stability) and the ability to adapt to changes (ecosystem elasticity) in a way that still retains the same structural and functional characteristics, or to reorganize and establish a new structural functional status. ${ }^{2}$

\section{ECOSYSTEM DIVERSITY}

Ecosystem diversity represents the total diversity of habitats (biotopes) and living communities (biocenoses) connected into a higher order - ecosystem (geobiocenosis), as well as all complex ecological processes that achieve the unity and functionality of biotopes and biocenoses integrated into ecosystems.

On Earth today, we recognize numerous and diverse ecosystems of lakes, bogs, swamps, rivers, streams, seas, coral reefs, deserts, steppes, savannas, meadows, pastures, thickets, deciduous and coniferous forests, mountain ridges, etc. Some ecosystems, such as tropical rainforests, are very complex and include a large number of species connected by multiple existential ties. Some other ecosystems, such as the African deserts or the Arctic tundra, have a much smaller number of species, are less complex, but are equally important because they

${ }^{2}$ EEA - European Environment Agency. 2012. Ecosystem resiliance and resource efficiency in a green economy in Europe. Environmental Indicator Report 2012. Luxembourg: Publications Office of the European Union. 
represent an unbreakable link in the chain of the Earth's biogeochemical cycle.

In general, the division of biological diversity into genetic, species and ecosystem diversity, primarily allows an analytical approach in the study and practical approach to a particular problem. However, the separation of these three levels of biological diversity should be understood as extremely conditional, because the basic feature of biological diversity is the interconnectedness and conditionality of all three levels of life forms and manifestations. Namely, all genetic informations are found in individuals and their populations within certain organic species, and at the same time, each individual, population and species belongs to certain ecosystems whose habitat conditions have adapted during long-term organic evolution. The process of adaptation is very long and leads to a high degree of organization which can be seen primarily through food chains, the circulation of matter and the flow of energy. Therefore, the survival of organisms, the functioning of their communities and the overall biosphere can be observed only through the unity, interconnectedness and conditionality of all life processes and changes in the environment. ${ }^{3}$

Different types of ecosystems are grouped in nature into larger spatial-functional units - biomes or large communities. Terrestrial biomes are mainly associated with certain climatic zones, so as biomes can be distinguished icy polar deserts, tundra, taiga, steppes, temperate deciduous forests, Mediterranean hardwood vegetation, deserts, savannas, deciduous tropical forests, evergreen tropical forests, high mountains. , oceans and inland waters.

Just as ecosystems unite into biomes, so do biomes unite into even larger spatial-functional units. These larger units are biocycles. There are three biocycles on Earth - the saltwater biocycle (seas and oceans), the freshwater biocycle (releases, springs, streams, rivers, lakes, ponds, swamps, marshes) and the land biocycle. All three biocycles build a superb, unique ecosystem of the Earth that is referred to as the biosphere. The biosphere means the entire area of the Earth inhabited by living world and its derivatives (organisms, pollen, spores, seeds, etc.).

This area or sphere includes the soil cover (pedosphere), the surface part of the lithosphere to a depth of $3 \mathrm{~km}$, the entire hydrosphere to a depth of over $11 \mathrm{~km}$ and part of the atmosphere to a height of $12 \mathrm{~km}$. The biosphere is the basic energy transformer on Earth, thanks to the green pigment chlorophyll, with which plants in the process of photosynthesis bind the electromagnetic energy of the Sun and convert it into the energy of chemical bonds. The functioning of the biosphere is reflected in the interconnectedness of its various ecosystems on the principle of the circulation of matter and the one-way flow of energy. This path of rotation of the basic elements, triggered by the action of solar energy, represents the biogeochemical cycles of matter on Earth.

\footnotetext{
${ }^{3}$ National Geography, (2011), Global Biodiversity, available at: https://www.nationalgeographic.org/article/globalbiodiversity/?utm_source=BibblioRCM_Row

${ }^{4}{ }^{4}$ National Geography, (2011), Global Biodiversity, available at: https://www.nationalgeographic.org/article/globalbiodiversity/?utm_source=BibblioRCM_Row
}

\section{BIODIVERSITY DISRUPTION FACTORS}

Biological diversity is very rapidly and rapidly reduced under the direct or indirect influence of man, his activity and the constant increase in the number of the human population. In the period from the appearance of anatomically modern man about 200,000 years ago, to about 10,000 years ago, ie until the beginning of the development of agriculture and animal husbandry, it is estimated that the planet was inhabited by about 10 million people. In the period until about 2000 years ago, the population increased to 200 million, and in 1836 it reached 1 billion. Today, the human population numbers more than 7 billion people. It is inevitable that all people have to live and eat somewhere.

Thus, due to the settlement of people in new environments, it caused negative changes in the biosphere, from the disappearance of a large number of biological species, through the introduction of species into new habitats, habitat destruction to the final reduction of biodiversity. It is believed that if the current pace of habitat destruction and biodiversity loss continues, the new century will be a period of the sixth mass extinction caused by the activity of one species, Homo sapiens. It has been determined that over $50 \%$ of recent vertebrate species and $12.5 \%$ of plant species are endangered. ${ }^{4}$

According to the IUCN (1996), ${ }^{5}$ endangered species categories are defined: extinct, critically endangered, endangered, vulnerable, and species with a low risk of extinction. The alarming situation is most pronounced in the island populations of animals, while in the framework of vascular plants, a much higher percentage are bare-seeded (32\%) compared to hidden-seeded $(9 \%)$. By applying different methods in estimating the rate of species extinction, a consensus was reached on the indicator of rapid rate increase, which is an increase of 1000 times in relation to the usual background rate of species extinction. Species extinction is one of the most important phenomena to explain the radiation of life forms throughout Earth's history. The extinction of species can be caused by the action of various factors, but it is first necessary to distinguish between the so-called. pseudoextinction or phyletic evolution and extinction of species. Namely, phyletic evolution represents a series of continuous evolutionary changes in one evolutionary line that over time leads to the emergence of a new biological entity and / or the division of a line or species into two or more (speciations). ${ }^{6}$

Pollution, overfishing, and overhunting have caused a drop in biodiversity. Global climate change-the latest rise in the average temperature around the globe, linked to human activityis also a factor. Warmer ocean temperatures damage fragile ecosystems such as coral reefs. A single coral reef can shelter 3,000 species of fish and other sea creatures such as clams and sea stars.

\footnotetext{
${ }^{5}$ IUCN (1996) International Union for the Conservation of Nature. Available at www.iucn.com

${ }^{6}$ Novičić Kurbalija Zorana. (2010), Biodiverzitet u krizi, available at : https://www.astronomija.org.rs/ivot/3579biodiverzitet-u-krizi
} 
Biodiversity can also be harmed by introduced species. When people introduce species from one part of the world to another, they often have no natural predators. These non-native species thrive in their new habitat, often destroying native species in the process.

The main reasons for the loss of biodiversity today can be represented by the acronym HIPPO: ${ }^{7}$

- $\quad \mathbf{H}=$ habitat alteration - the largest number of species is lost today because man has disturbed their habitats with his activity. The protection of a species is worthless if its habitat is not protected (a complex of biotic and abiotic factors). When a habitat is lost, the return of the species is very difficult and the success of the reintroduction depends on how well the habitat and the conditions that prevail on it have been preserved. The most common type of habitat disturbance is its fragmentation (dams, agricultural areas, urbanization, infrastructure ...). In the original habitat, openings are made, cavities, the unique habitat is divided into individual parts. The cavities expand, the original habitat becomes smaller and smaller, the parts become more and more isolated, gene flow is lost and inbreeding and genetic loads occur. The gene corridor is very important in the concept of protection in order to enable the exchange of genetic material. In Canada, they build entire forest complexes for bears via highways.

- I = invasive species (invasive, introduced, non-native species) - the problem with these species is that there is no control over them (they are not in the complex of biotic relations with organisms that are within the living communities in which they are introduced, they have no natural enemies will regulate their number) and create big problems in relation to the autochthonous flora and fauna. Examples are the rabbit in Australia, the leper in America, and the potato beetle in Europe.

- $\quad \mathbf{P}=$ polution (pollution) - a specific type of habitat disturbance. Due to its extremely high intensity, it deserves to be recognized as a special reason. It represents the addition of energy and certain substances to the media of the environment, which cannot be decomposed, that is. enter biogeochemical cycles.Example of Pollution: On March 24, 1989, the Exxon Waldez tanker ran aground on the shores of the west coast of Alaska. On that occasion, 42 million liters of crude oil spilled into the Pacific. This accident is considered the largest of its kind in the history of the United States. Oil covered $2,100 \mathrm{~km}$ of the coast of

\section{${ }^{7}$ Tschakert Petra et al., (2019), Threats to Biodiversity, available at https://www.e- education.psu.edu/geog30/node/394}

\footnotetext{
${ }^{8}$ National Geography, (2011), Global Biodiversity, available at: https://www.nationalgeographic.org/article/globalbiodiversity/?utm_source=BibblioRCM_Row

${ }^{9}$ Environment and Climate Change Canada. 2019. Summary of Canada's 6th National Report to the Convention on Biological
}

Alaska (the size of the entire Adriatic). On that occasion, 100,000-400,000 birds died; 2600-5500 sea otters; 500800 seals and countless fish. ${ }^{8}$

- $\mathbf{P}=$ population growth of human (excessive, exponential growth of human population). This phenomenon directly causes the following.

- $\mathbf{O}=$ overexploitation - excessive exploitation of natural resources, which directly results from the exponential growth of the human population. Biological resources are renewable, but the level of their reproducibility is often much lower than the level of exploitation, the level of exploitation is often higher in relation to the reproductive potential of the species. The history of the human race is the history of man's relationship to biological resources. The resources themselves are a physical manifestation of biological diversity. They can include genes and species and ecosystems. An example of the misuse of biological resources is the hunting of white sharks because of the belief in the aphrodisiac properties of the dorsal fin or rhino because of the belief in the same properties of their horn. ${ }^{9}$

\section{BIODIVERSITY PROTECTION}

In response to the increasing fragmentation of habitats caused by the expansion of agricultural land, infrastructure, urban and industrial centers, the concept of ecological networks began to develop during the 1970s. Ecological networks represent a modern approach to nature protection with the basic goal of connecting fragmented habitats and parts of ecosystems into functional ecological systems.

The basic characteristics of ecological networks are:

- conservation of biological diversity at the level of landscapes, ecosystems or regions

- emphasis on preserving and improving the ecological integrity and functionality of ecosystems

- improved connectivity within the target area

- existence of zones to ensure connectivity and protection of central areas promotion of revitalization of degraded habitats where possible

- promotion of sustainable use of resources in areas important for the conservation of biological diversity. ${ }^{10}$

In order to ensure the functionality of ecological networks, they are planned as a set of individual elements, each of which has a specific function in the network. The basic spatial elements of ecological networks are:

Diversity. Gatineau, QC: Government of Canada. Available at: https://biodivcanada.chm-cbd.net/sites/biodivcanada/files/inlinefiles/EN_Summary\%20of\%20Canada\%27s\%206th\%20National $\%$ 20Report_Final_1.pdf

${ }^{10}$ IUCN, (2011), European Union policies and strategies in the field of environment in Southeast Europe, Manual for training of civil society organizations from Southeast Europe on the application of EU legislation in the field of nature protection, available at: https://portals.iucn.org/library/sites/library/files/documents/2011111-Sr.pdf 
- central areas as areas of the greatest importance for biodiversity conservation. They cover protected areas and habitats based on different criteria for designation such as protected areas according to IUCN categories, Natura 2000 areas, Ramsar sites, IBA, IPA, PBA.

- corridors, which connect the central areas into an ecologically functional network. Corridors can be of the linear type, mosaics of different habitats connected into one whole, or they can represent physically separate areas that serve the migration of species. Corridors are the most complex parts of ecological networks because they are most often located outside protected areas in resource-managed areas where the application of protection measures is more complex.

- protection area is defined in order to protect the central areas and corridors from negative external influences. The use of resources in the protected area should be compatible with the central areas around which it is established. ${ }^{11}$

Ecological network management means the management of individual ecologically significant areas and ecological corridors, in order to maintain and improve the functional integrity of the ecological network. Involving the local population is crucial for defining any ecological network, especially in areas outside protected areas that are, to a greater or lesser extent, managed in order to use resources. ${ }^{12}$ Awareness of nature protection and its goals is set as one of the first conditions in this process. Involvement of the local population is of crucial importance because these are the users of the space who are expected to apply nature protection measures, which, on the other hand, in some cases result in decreasing in income from activities such as agriculture, forestry, etc.

\section{CONCLUSION}

Through all his activities, man very often unnecessarily, recklessly, ignorantly, arrogant and above all greedy, destroys many habitats and species in order to obtain enormous material profit, not to meet basic existential needs. So we came to the situation that man has changed the appearance of the Earth with his activity and significantly damaged the biosphere. On the huge areas of the planet are completely destroyed natural ecosystems (forests, steppes, swamps) or have been replaced by artificial ones (plantations, farms, settlements). That little bit of nature, which still exists as untouched, is slowly disappearing under the pressure of man.

Protection and preservation of biological diversity has become one of the most important issues of humanity, and the science of biological diversity has been promoted into one of the most important sciences in the new millennium. There are many

\footnotetext{
${ }^{11}$ Ibid

${ }^{12}$ IUCN, (2011), European Union policies and strategies in the field of environment in Southeast Europe, Manual for training of civil society organizations from Southeast Europe on the application of EU legislation in the field of nature protection,
}

threats to biodiversity today. The biggest ones can be remembered by using the acronym H.I.P.P.O.: Habitat Loss, Invasive Species, Pollution, Human Population, and Overharvesting.

To preserve biodiversity we need to carry out actions and pass laws on nature protection environment at world conventions but also at the state level. It is especially important to raise people's awareness about environmental protection.

Ecological network models are useful and quality tool for quantifying how ecosystems work. Analysis of ecological network can provide precise metrics that quantify community structure and models for analyzing ecosystem resiliency and stability in a habitual and extreme conditions. Quantifying and testing all possible ecological network characteristics may yield crucial information about impact and vulnerability to multiple stressors not only for the parts, but for the whole ecosystem.

\section{REFERENCES}

[1] Millennium Ecosystem Assessment (2005): Ecosystems and Human Wellbeing: Synthesis. Island Press, Washington, DC.

[2] Mani, M., Markandya, A. and Ipe, V. (2008). Policy and Institutional Reforms to Support Climate Change Adaptation and Mitigation in Development Programs, pp 78. Washington: The International Bank for Reconstruction and Development; The World Bank.

[3] EEA - European Environment Agency. (2012). Ecosystem resiliance and resource efficiency in a green economy in Europe. Environmental Indicator Report 2012. Luxembourg: Publications Office of the European Union.

[4] IUCN (1996) International Union for the Conservation of Nature. Available at www.iucn.com

[5] Novičić Kurbalija Zorana. (2010), Biodiverzitet u krizi, available at : https://www.astronomija.org.rs/ivot/3579-biodiverzitet-u-krizi

[6] IUCN, (2011), European Union policies and strategies in the field of environment in Southeast Europe, Manual for training of civil society organizations from Southeast Europe on the application of EU legislation in the field of nature protection, available at: https://portals.iucn.org/library/sites/library/files/documents/2011-111-Sr.pdf

[7] Tschakert Petra et al., (2019), Threats to Biodiversity, available at https://www.e-education.psu.edu/geog30/node/394

[8] National Geography, (2011), Global Biodiversity, available at: https://www.nationalgeographic.org/article/globalbiodiversity/?utm_source=BibblioRCM_Row

[9] Environment and Climate Change Canada. (2019). Summary of Canada's 6th National Report to the Convention on Biological Diversity. Gatineau, QC: Government of Canada. https://biodivcanada.chmcbd.net/sites/biodivcanada/files/inlinefiles/EN_Summary\%20of\%20Canada\%27s\%206th\%20National\%20Report _Final_1.pdf

\section{AUTHORS}

First Author - Ali Farag Alznad Phd ,Candidate

available at:

https://portals.iucn.org/library/sites/library/files/documents/2011111-Sr.pdf 
